\title{
Peningkatan Hasil Belajar Matematika Siswa dengan Menerapkan Model Pembelajaran Talking Stick
}

\author{
1 Isnaeni \\ 2Muhaemin \\ ${ }^{3}$ Hasri \\ ${ }^{1}$ Program Studi Tadris Matematika, FTIK, IAIN Palopo \\ E-mail: isnaeni iainpalopo@gmail.com
}

\begin{abstract}
This article aims to see the improvement of students' mathematics learning outcomes by using the talking stick teaching model. The type of research used is classroom action research designed two cycles in accordance with the achievement of indicators. The subjects are all students of class VIII Madrasah Tsanawiyah No 32 Lamasi Kecamatan Lamasi Kabupaten Luwu, amounting to 21 people. The instruments used were test and observation. Before treatment, the average student's learning outcomes of 50.95. If associated with the indicator of success is 70 , then the student is not yet complete in learning mathematics. This is also an indication that there is a problem in learning mathematics in that class. After the applied model of talking stick, the average value of students increased in cycle I to 65.23 but there are still 11 students who have not completed. The study then continued to cycle II and the average of mathematics learning outcomes increased to 80.38 with 17 students already completed or $80.95 \%$. If it is associated with the indicator where the research is said to be successful if the students who get a minimum score of 70 amounted to at least $80 \%$ then this research has been successful and stopped until the second cycle. Student and teacher activity also showed positive results. From the observation seen there is improvement of mental attitude of student in expressing its opinion from $57,1 \%$ student increase to $85,7 \%$. The same for student responses in answering teacher questions increased from 52.3\% to 90.4\%. Teacher activity increased slightly from $50.0 \%$ to $50.84 \%$. Of all the results it is clear that the learning model of talking stick can improve students' mathematics learning outcomes.
\end{abstract}

Keywords: Talking Stick Teaching Model, Mathematics Learning Outcomes.

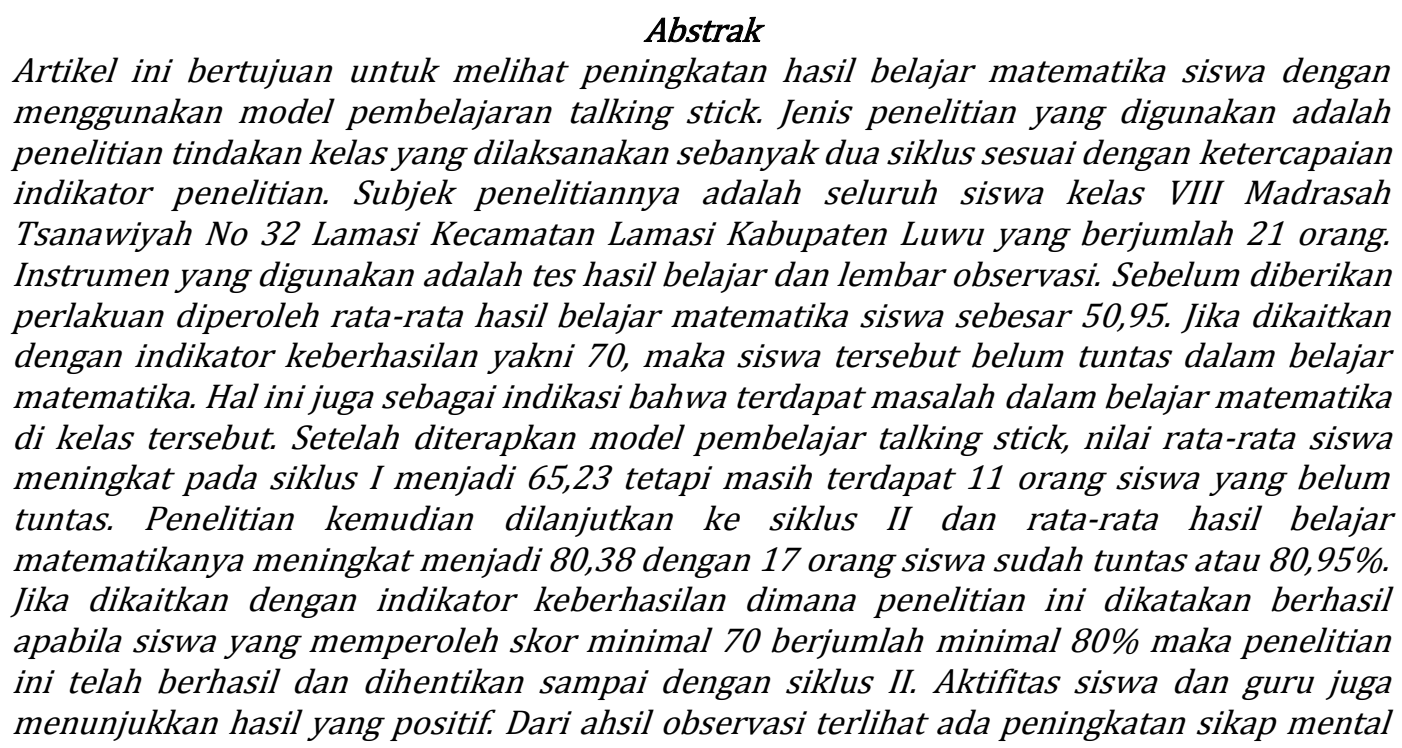


siswa dalam mengemukakan pendapatnya dari 57,1\% siswa meningkat menjadi 85,7\%. Hal yang sama untuk respon siswa dalam menjawab pertanyaan guru meningkat dari 52,3\% menjadi 90,4\%. Aktifitas guru mengalami sedikit peningkatan dari 50,0\% menjadi 50,84\%. Dari semua hasil tersebut jelas bahwa model pembelajaran talking stick mampu meningkatkan hasil belajar matematika siswa.

Kata Kunci: Model Pembelajaran Talking Stick, Hasil Belajar Matematika.

\section{Pendahuluan}

Pembelajaran matematika diarahkan agar siswa mampu berfikir rasional dan kreatif, mampu berkomunikasi dan tangguh menghadapi masalah serta mampu mengubah masalah menjadi peluang. Aktifitas siswa mengonstruksi berbagai sikap, sifat, dan aturan matematika melalui pemecahan masalah kompleks. Komunikasi dan kerjasama diantara siswa dalam memahami, menganalisis, berfikir kritis dan kreatif dalam memecahkan masalah menjadi fokus utama dari guru.

Belajar adalah suatu proses usaha yang dilakukan seseorang untuk memperoleh suatu perubahan tingkah laku yang baru secara keseluruhan, sebagai hasil pengalamannya dalam interaksi dengan lingkungannya ${ }^{1}$. Hal ini sejalan dengan yang dinyatakan Syaiful Bahri Zain tentang belajar bahwa belajar adalah proses perubahan perilaku berkat pengalaman dan latihan. Artinya tujuan kegiatan adalah perubahan tingkah laku, baik yang menyangkut pengetahuan, keterampilan, maupun sikap, bahkan meliputi segenap aspek organisme atau pribadi ${ }^{2}$.

Berdasarkan hasil survey awal terlihat bahwa masih ada sebagian siswa yang mengalami kesulitan dalam pembelajaran matematika. Lebih lanjut, masih ada sebagian siswa yang nilainya belum mencapai Keriteria Ketuntasan Minimal (KKM). Hal tersebut diakibatkan oleh kurangnya minat sebagian besar siswa terhadap pembelajaran matematika, mereka menganggap bahwa matematika itu pelajaran yang sangat rumit dan

${ }^{1}$ Slameto, Belajar Dan Faktor Yang Mempengaruhinya (Jakarta: Rineka Cipta, 1995), 2.

2 Darsono Max, Belajar dan Pembelajaran (Semarang: IKIP Semarang Press, 2000), $30-31$. 


\section{Implementasi Pendidikan Karakter...}

menakutkan sehingga kebanyakan mereka tidak menyukai pembelajaran matematika.

Pembelajaran matematika di Madrasah Tsanawiyah No.32 Lamasi Kec. Lamasi Kab. Luwu masih dikelola dengan biasa. Artinya variasi dalam menerapkan model pembelajaran sangat terbatas dan cenderung menerapkan model pembelajaran yang terpusat pada guru. Hal ini menyebabkan siswa cepat jenuh dan kurang merasa semangat dalam belajar matematika.

Model pembelajaran yang dilakukan oleh guru juga merupakan salah satu yang mendukung keberhasilan dalam proses belajar-mengajar. Jika guru mengetahui model yang cocok untuk siswa dalam pembelajaran matematika dalam penyampaiannya siswa tidak akan bosan dalam proses belajar dikelas. Model pembelajaran yang baik adalah model yang dapat membuat siswa secara aktif menggali pemecahan masalah yang dihadapi dan dapat membuat siswa mandiri meskipun pembelajaran sudah berakhir. Dalam pembelajaran matematika perlu diupayakan model pembelajaran yang baik. Model pembelajaran talking stick salah satu model pembelajaran yang dapat mendorong siswa untuk berani mengemukakan pendapatnya ${ }^{3}$. Talking stick adalah model pembelajaran dengan bantuan tongkat, siapa yang memegang tongkat wajib menjawab pertanyaan dari guru setelah siswa mempelajari materi pokoknya.

Model pembelajaran talking stick melatih siswa dalam membaca dan memahami pelejaran dengan cepat, menguji kesiapan dan mendorong siswa giat belajar. Hanya saja model pembelajaran ini menuntut guru untuk terus aktif membimbing siswa dalam beraktifitas di kelas. model pembelajarn ini pada umumnya cocok untuk semua pokok bahasan dalam matematika tingkat SMP/Madrasa Tsanawiyah hanya saja perlu dipertimbangkan efektifitas waktu dalam belajar mengingat model pembelajaran ini memiliki konsep bermain sambil belajar.

\footnotetext{
${ }^{3}$ Agus Suprijono, Cooperative Learning; Teori Dan Aplikasi PAIKEM (Yogyakarta: Pustaka Pelajar, 2009), 109.
} 
Berdasarkan hal tersebut, maka dalam artikel ini akan diuraikan penerapan model pembelajaran talking stick dalam meningkatkan hasil belajar matematika siswa kelas VIII Madrasah Tsanawiyah No.32 Lamasi Kec. Lamasi Kab. Luwu.

\section{Kerangka Teoretis}

Model pembelajaran talking stick merupakan model pembejalaran yang cukup menarik dan telah diterapakn oleh beberapa peneliti sebelumnya. Beberapa diantaranya adalah penerapan talking stick dalam meningkatkan keaktifan siswa kelas VII SMP Negeri 1 Nogosari ${ }^{4}$ dan penerapan takling stick dalam meningkatkan aktifitas belajar matematika siswa kelas VII SMP Negeri 3 Kartasura pada pokok bahasan persegi dan persegi panjang5. Kedua penelitian tersebut menunjukkan bahwa talking stick merupakan model pembelajaran yang cukup menyenangkan dan dapat diterapakan di dalam kelas.

Langkah-langkah model pembalajaran talking stick antaralain:

1. Guru memberikan materi yang akan dipelajari dan memberikan kesempatan kepada siswa untuk membaca dan mempelajari materi, pada tahap ini guru menyampaikan materi pokok yang akan dipelajari, kemudian memberikan kesempatan kepada siswa untuk membaca dan mempelajari materi pada pegangannya.

2. Guru mengambil tongkat, memberikan pertanyaan. Pada tahap ini guru mempersilahkan siswa untuk menutup bukunya kemudian guru mengambil tongkat dan memberikan kepada siswa, setelah itu guru

${ }^{4}$ Rista Kurniawati, "Peningkatan Keaktifan Siswa Dalam Pembelajaran Matematika Dengan Menggunakan Strategi Pembelajaran Talking Stick (PTK Pembelajaran Matematika Kelas VII Semester Genap SMP N 1 Nogosari Tahun Ajaran 2010/2011)" (Universitas Muhammadiyah Surakarta, 2011), https://doi.org/Kurniawati, Rista (2011) Peningkatan Keaktifan Siswa Dalam Pembelajaran Matematika Dengan Menggunakan Strategi Pembelajaran Talking Stick (PTK Pembelajaran Matematika Kelas VII Semester Genap SMP N 1 Nogosari Tahun Ajaran 2010/2011). Skripsi thesis, Universitas Muhammadiyah Surakarta.

5 Filein Sofiawati, "Peningkatan Aktivitas Belajar Matematika Melalui Metode Cooperative Learning Tipe Talking Stick (PTK Pada Siswa Kelas VII SMP Negeri 3 Kartasura)" (Universitas Muhammadiyah Surakarta, 2010), http://eprints.ums.ac.id/8332/. 


\section{Implementasi Pendidikan Karakter...}

memberikan pertanyaan dan siswa yang memegang tongkat tersebut harus menjawabnya, demikian seterusnya sampai sebagian besar siswa mendapat bagian untuk menjawab setiap pertanyaan dari guru.

3. Guru memberikan rangkuman dari materi yang telah dipelajari, pada tahap ini guru memberi kesimpulan dan memberikan soal tes kepada siswa.

\section{Metode dan Hasil Penelitian}

Penelitian ini merupakan penelitian tindakan kelas (Classroom Action Research) dengan ciri kolaboratif dan dalam bentuk siklus. Lokasi penelitian yaitu Madrasah Tsanawiyah dengan subjek penelitian siswa kelas VIII yang berjumlah 21 orang. Penelitian ini dimulai dari identifikasi masalah, menyusun perencanaan, melaksanakan tindakan, melakukan observasi, dan mengadakan refleksi. ${ }^{6}$ Instrumen yang digunakan dalam penelitian ini antara lain tes hasil belajar dan lembar observasi. Indikator keberhasilan dalam penelitian ini adalah siswa dikatakan tuntas belajar apabila skor hasil tes belajarnya minimal 70. Ketuntasan klasikal tercapai apabila jumlah siswa yang tuntas belajar minimal $80 \%$.

\section{Deskripsi Hasil Tes Awal}

Sebelum diberikan tindakan, terlebih dahulu dilakukan tes awal untuk melihat sekaligus mempertegas hasil observasi awal yang menyatakan bahwa hasil belajar matematika siswa di kelas VIII tersebut cenderung rendah. Hasil tes awal tersebut dapat dilihat pada Tabel 1 berikut:

${ }^{6}$ Wina Sanjaya, Penelitian Tindakan Kelas, 1st ed., 3 (Jakarta: Kencana, 2011). 
Tabel 1. Skor Tes Awal

\begin{tabular}{cc}
\hline Statistik & Nilai Statistik \\
\hline Subjek & 21 \\
\hline Rata-rata (Mean) & 50,95 \\
\hline Median & 50,00 \\
\hline Std. Devition & 12,81 \\
\hline Variance & 164,34 \\
\hline Range & 45 \\
\hline Minimum & 35 \\
\hline Maximum & 80 \\
\hline Sum & 1070
\end{tabular}

Sumber: Data Olahan Hasil Penelitian

Apabila dikategorikan, maka gambaran keadaan siswa berdasarkan skor tes awal adalah seperti yang terlihat pada Tabel 2 dan Tabel 3 berikut:

Tabel 2. Kategorisasi Skor Tes Awal

\begin{tabular}{cccc}
\hline Skor & Kategori & Frekuensi & Persentase (\%) \\
\hline $0-54$ & Sangat kurang & 13 & $61,9 \%$ \\
\hline $55-64$ & Kurang & 5 & $23,8 \%$ \\
\hline $65-74$ & Cukup & 1 & $4,8 \%$ \\
\hline $75-84$ & Baik & 2 & $9,5 \%$ \\
\hline $85-100$ & Sangat baik & 0 & - \\
\hline \multicolumn{2}{c}{ Jumlah } & 21 & $100 \%$ \\
\hline
\end{tabular}

Sumber: Data Olahan Hasil Penelitian

Tabel 3. Kategorisasi Ketuntasan Skor Tes Awal

\begin{tabular}{|c|c|c|c|c|}
\hline No & Skor & Kategori & Frekuensi & Persentase \\
\hline 1 & $<70$ & Tidak Tuntas & 18 & $85,7 \%$ \\
\hline 2 & $\geq 70$ & Tuntas & 3 & $14,3 \%$ \\
\hline \multicolumn{3}{|c|}{ Jumlah } & 21 & $100 \%$ \\
\hline
\end{tabular}

Sumber: Data Olahan Hasil Penelitian

Deskripsi Hasil Tes Siklus I

Berdasarkan deskripsi skor tes awal terlihat bahwa hasil belajar matematika siswa masih tergolong rendah. Untuk itu ditetapkan untuk diberikan tindakan di dalam kelas untuk meningkatkan hasil belajar matematika siswa. Tindakan yang disepakati adalah dengan menerapakn 


\section{Implementasi Pendidikan Karakter...}

model pembelajaran talking stick. Deskripsi skor hasil belajar matematika siswa dan kategorisasinya dapat secara berurut dapat dilihat pada Tabel 4, Tabel 5, dan Tabel 6 berikut:

Tabel 4. Skor Tes Siklus I

\begin{tabular}{cc}
\hline Statistik & Nilai Statistik \\
\hline Subjek & 21 \\
\hline Rata-rata (Mean) & 65,23 \\
\hline Median & 65,00 \\
\hline Std Deviation & 14,35 \\
\hline Variance & 206,19 \\
\hline Range & 55,00 \\
\hline Skor Minimum & 40,00 \\
\hline Skor Maximum & 95,00 \\
\hline Sum & 1370
\end{tabular}

Sumber: Data Olahan Hasil Penelitian

Tabel 5. Kategorisasi Ketuntasan Skor Siklus I

\begin{tabular}{cccc}
\hline Skor & Kategori & Frekuensi & Persentase(\%) \\
\hline $0-54$ & Sangat Kurang & 5 & 23,81 \\
\hline $55-64$ & Kurang & 5 & 23,81 \\
\hline $65-74$ & Cukup & 4 & 19,05 \\
\hline $75-84$ & Baik & 5 & 23,81 \\
\hline $85-100$ & Sangat Baik & 2 & 9,52 \\
\hline & Jumlah & 21 & $100 \%$ \\
\hline
\end{tabular}

Sumber: Data Olahan Hasil Penelitian

Tabel 6. Kategorisasi Ketuntasan Skor Tes Siklus I

\begin{tabular}{ccccc}
\hline No & Skor & Kategori & Frekuensi & Persentase (\%) \\
\hline 1 & $<70$ & Tidak Tuntas & 11 & $52,4 \%$ \\
\hline 2 & $\geq 70$ & Tuntas & 10 & $47,6 \%$ \\
\hline \multicolumn{2}{c}{ Jumlah } & 21 & $100 \%$ \\
\hline
\end{tabular}

Sumber: Data Olahan Hasil Penelitian

Pada pertemuan pertama, guru menjelaskan tentang materi pelajaran. Setelah itu memberikan kesempatan kepada siswa untuk membaca kembali materi yang telah mereka tuliskan. Namun, sebagian siswa merasa kesulitan dalam mempelajari kembali materi yang telah diberikan, hal tersebut 
dikarenakan waktu yang diberikan kepada siswa hanya 10 menit sehingga siswa tidak memiliki waktu untuk fokus menyelesaikan tugasnya. Kemudian guru mempersilahkan siswa untuk berdiri dan membentuk suatu lingkaran sebelum memberikan tongkat kepada salah satu siswa dan menyanyikan sebuah lagu sambil tongkat diserahkan dari siswa satu ke siswa yang lainnya. Setelah lagu selesai guru memberikan pertanyaan kepada siswa yang memegang tongkat. Pada saat siswa memberikan jawaban terkadang terdapat siswa yang merasa kurang percaya diri, grogi, dan masi ragu-ragu dalam menjawab pertanyaan, bahkan terdapat siswa yang sama sekali tidak dapat menjawab pertanyaan dengan baik dari guru. Melihat situasi demikian mengharuskan guru mengambil tindakan dengan mendatangi siswa tersebut kemudian membimbing siswa tersebut dalam menyelesaikan pertanyaan yang diberikan.

Pada pertemuan kedua, motivasi dan semangat siswa untuk belajar semakin meningkat. Hal ini terlihat pada saat pemberian materi siswa benarbenar memperhatikan apa yang telah dijelaskan. Siswa juga tidak segansegan untuk bertanya apabila ada yang kurang dimengerti. Akibatnya, siswa tidak terlalu sulit untuk mempelajari kembali materi yang telah diberikan.

Kendala utama yang terjadi pada siklus I adalah terbatasnya waktu yang tersedia untuk mempelajari. Akibatnya pada saat guru memberikan pertanyaan, siswa yang tidak terlalu menguasai materinya mengalami kesulitan untuk menjawab pertanyaan.

\section{Deskripsi Hasil Tes Siklus II}

Siklus II dilaksanakan karena indikator keberhasilan yang ditentukan di awal belum terpenuhi. Catatan refleksi diri kemudian dievaluasi dan diperbaiki pada siklus II. Deskripsi skor hasil belajar matematika siswa dan kategorisasinya secara berurut dapat dilihat pada Tabel 7, Tabel 8, dan Tabel 9 berikut: 
Implementasi Pendidikan Karakter...

Tabel 7. Skor Tes Siklus II

\begin{tabular}{cc}
\hline Statistik & Nilai Statistik \\
\hline Subjek & 21 \\
\hline Rata-rata (Mean) & 80,38 \\
\hline Median & 85,00 \\
\hline Std Deviation & 12,67 \\
\hline Variance & 160,54 \\
\hline Range & 40 \\
\hline Skor Minimum & 60 \\
\hline Skor Maximum & 100 \\
\hline Sum & 1688
\end{tabular}

Sumber: Data Olahan Hasil Penelitian

Tabel 5. Kategorisasi Ketuntasan Skor Siklus I

\begin{tabular}{cccc}
\hline Skor & Kategori & Frekuensi & Persentase(\%) \\
\hline $0-54$ & Sangat Kurang & 0 & $0 \%$ \\
\hline $55-64$ & Kurang & 3 & $14,29 \%$ \\
\hline $65-74$ & Cukup & 4 & $19,05 \%$ \\
\hline $75-84$ & Baik & 2 & $9,52 \%$ \\
\hline $85-100$ & Sangat Baik & 12 & $57,14 \%$ \\
\hline & Jumlah & 21 & 21 \\
\hline
\end{tabular}

Sumber: Data Olahan Hasil Penelitian

Tabel 6. Kategorisasi Ketuntasan Skor Tes Siklus I

\begin{tabular}{ccccc}
\hline No & Skor & Kategori & Frekuensi & Persentase (\%) \\
\hline 1 & $<70$ & Tidak Tuntas & 4 & $19,05 \%$ \\
\hline 2 & $\geq 70$ & Tuntas & 17 & $80,95 \%$ \\
\hline \multicolumn{2}{c}{ Jumlah } & 21 & $100 \%$ \\
\hline
\end{tabular}

Sumber: Data Olahan Hasil Penelitian

Pada siklus II ini, keterbatasan waktu sudah dapat diminimalkan, karena siswa lebih cepat memahami materi yang diberikan. Ketika siswa yang memegang tongkat diberikan pertanyaan, siswa tersebut langsung menjawab pertanyaan dengan percaya diri tanpa.

Pembelajaran dengan menggunakan model pembelajaran talking stick memperlihatkan aktivitas siswa yang berbeda. Siswa terlihat lebih semangat dalam belajar dan lebih serius memperhatikan ketika guru sedang 
menjelaskan. Siswa juga lebih aktif bertanya ketika ada pembelajaran yang belum dipamahami.

Hampir semua siswa menyenangi pembelajaran dengan model talking stick dengan alasan bahwa pembelajaran dengan model talking stick merupakan model pembelajaran yang menantang, menghibur, ceria dan juga sebagian besar siswa mengatakan bahwa belajar dengan menggunakan model talking stick dapat meningkatkan semangat dan minat siswa dalam belajar matematika.

\section{Penutup}

Berdasarkan hasil penelitian dan pembahasan, maka dapat disimpulkan beberapa hal sebagai berikut:

1. Penerapan dengan model pembelajaran talking stick yaitu pembelajaran dengan menggunakan tongkat siapa yang memegang tongkat wajib menjawab pertanyaan dari guru, adapun cara pelaksanaan model pembelajaran talking stickyaitu:

a. Guru memberikan materi pokok kepada siswa.

b. Guru memberikan kesempatan kepada siswa untuk membaca atau memepelajari kembali materi yang telah diberikan.

c. Guru menginformasikan kepada siswa untuk menutup atau menyimpan bukunya setelah selesai dibaca.

d. Guru memberikan tongkat kepada salah satu siswa dan menyuruh siswa menjalankan tongkat tersebut dari satu siswa ke siswa yang lainnya sambil menyanyikan sebuah lagu.

e. Guru memberikan pertanyaan kepada siswa yang terakhir memegang tongkat.

f. Guru menyuruh siswa menjawab pertanyaan di atas papan tulis.

2. Pembelajaran dengan menggunakan model talking stick dapat meningkatkan hasil belajar matematika siswa. Hal ini disebabkan karena dalam model pembelajaran talking stick siswa sangat antusias untuk belajar sebab pada model ini terdapat unsur permainan didalamnya, kemudian siswa dituntut untuk lebih aktif dan mengemukakan 
Implementasi Pendidikan Karakter...

pendapatnya dalam proses pembelajaran sehingga pemahaman siswa terhadap materi dapat meningkat.

\section{Daftar Pustaka}

Filein Sofiawati. "Peningkatan Aktivitas Belajar Matematika Melalui Metode Cooperative Learning Tipe Talking Stick (PTK Pada Siswa Kelas VII SMP Negeri 3 Kartasura)." S1, Universitas Muhammadiyah Surakarta, 2010. http://eprints.ums.ac.id/8332/.

Kurniawati, Rista. "Peningkatan Keaktifan Siswa Dalam Pembelajaran Matematika Dengan Menggunakan Strategi Pembelajaran Talking Stick (PTK Pembelajaran Matematika Kelas VII Semester Genap SMP N 1 Nogosari Tahun Ajaran 2010/2011)." S1, Universitas Muhammadiyah Surakarta, 2011. https://doi.org/Kurniawati , Rista (2011) Peningkatan Keaktifan Siswa Dalam Pembelajaran Matematika Dengan Menggunakan Strategi Pembelajaran Talking Stick (PTK Pembelajaran Matematika Kelas VII Semester Genap SMP N 1 Nogosari Tahun Ajaran 2010/2011). Skripsi thesis, Universitas Muhammadiyah Surakarta.

Max, Darsono. Belajar dan Pembelajaran. Semarang: IKIP Semarang Press, 2000.

Sanjaya, Wina. Penelitian Tindakan Kelas. 1st ed. 3. Jakarta: Kencana, 2011.

Slameto. Belajar Dan Faktor Yang Mempengaruhinya. Jakarta: Rineka Cipta, 1995.

Suprijono, Agus. Cooperative Learning; Teori Dan Aplikasi PAIKEM. Yogyakarta: Pustaka Pelajar, 2009. 
Isnaeni, Muhaemin, \& Hasri

Halaman ini sengaja dikosongkan

Al-Khwarizmi - 142 